\title{
Factors Influencing the Earnings Expectations among Macedonian Students: A Comparative Perspective with the EU Students
}

\section{Marija Andonova}

School of Business Economics and Management, University American College-Skopje, Macedonia

nacova@uacs.edu.mk

\section{Nikica Mojsoska-Blazevski}

School of Business Economics and Management, University American College-Skopje, Macedonia

nikica@uacs.edu.mk
CroEconSur

Vol. 17

No. 1

June 2015

pp. $71-110$

Received: September 8, 2014 Accepted: March 27, 2015

Research Article

doi:10.15179/ces.17.1.3

\section{Abstract}

The aim of this paper is to assess the earnings expectations of Macedonian students and the main factors that shape their expectations. Previous research has shown that earnings expectation is a major determinant that influences a decision on schooling (Williams and Gordon, 1981; Betts, 1996; Wolter and Zbinden, 2001). Given that the main pathway to developing individual human capital is schooling, learning about factors that affect individual's decision on whether to acquire more education can contribute towards better educational policy. We employ similar empirical approach as Brunello et al. (2001, 2004). We use available information to regress: i) expected future earnings right after university graduation and ii) expected future earnings 10 years after graduation, on a set of variables: characteristics of the individual, socio-economic background, 
field of study, year of study, academic performance, sources of information for future earnings, etc.

Our findings show that expected earnings are significantly correlated with the education of the father, year of study, sources of information on earnings in the labor market, gender, ethnicity, having a regular job during studies, perceived employability, field of study, and the country of future employment. In other words, Macedonian students form their earnings expectations in a similar vein as their European counterparts.

Keywords: demand for schooling, earnings expectations, higher education

JEL classification: I21, I23, J24

\section{Introduction}

Since 2003 the Macedonian higher education system has undergone several important reforms, mainly related to the implementation of the Bologna Declaration which was signed in 2003. The actual implementation of the Bolognarelated reforms started in 2008 when a new Law on Higher education was adopted reflecting the Bologna declaration. The Law was developed around the following premises: strengthening the quality assurance system; internationalization of universities, their programs, and students; involvement of students and employers into the decision-making bodies of universities; membership of the national bodies for quality assurance in the European Association for Quality Assurance in Higher Education (ENQA), etc. In addition, the two-cycle system was replaced with a three-cycle system. However, some state universities faced difficulties in conforming to the new higher education environment and requirements, such that some of them still offer 4-years undergraduate programs or even 5 or 6 years of undergraduate programs in the field of regulated professions (Vujacic et al., 2013). 
Recent years are characterized by the expansion of provision and subsidies in the Macedonian tertiary education system. Two new state universities were established, and dispersed studies were organized across the country (as cobranches of state universities), improving the access to tertiary education for most youth. In addition, the tuition fees at state universities were reduced (and subsidies increased). These factors have contributed to a large increase in university enrollments, with the gross enrollment rate growing from 24 percent in 2005/06 to 31 percent in 2011/12 (State Statistical Office, 2013). Between 2000 and 2011, the number of graduates tripled (State Statistical Office, 2012). However, the increased relative supply of workers with tertiary education brought about declining returns to education, both in terms of employment and wages of the graduates (Mojsoska-Blazevski and Ristovska, 2012).

In the academic year 2013/14, there were 16 universities, 5 of which were state universities. The majority of students were enrolled at state universities (88.5 percent). The expansion of the state universities contributed towards an increase in their share in total number of students from 82 percent in 2010 to 87 percent in 2013/2014.

Benefits from getting a university degree in labor economics are measured through returns to education: earnings returns and returns in terms of probability for getting a job. In Macedonia, there are relatively high returns to education: individuals who have completed 4-year secondary school have, on average, 37 percent higher earnings than those who have completed only primary education, while getting a university degree increases earnings by 106 percent compared to having just primary education (Mojsoska, 2006). Similarly, the probability of employment increases with education, in such a way that workers who have completed tertiary education in 2011 had 2.5 times higher employment rates than individuals who have completed only primary education. Hence, there are large incentives for young individuals to demand more education. However, so far no study has been done in Macedonia on the factors driving earnings expectations of students and hence their demand for education. For instance, 
there is no evidence on whether students are realistic about the market value of their labor after graduating from university. What is their expectation on potential gender-earnings gap? Which characteristics of students and their social environment influence the expected earnings?

While the literature on returns to education is very broad, few studies have attempted to answer these questions. Most of the studies of earnings expectations are related to US and European experience, with no similar studies conducted either for the transition countries or the Western Balkans countries. In this respect, the aim of this paper is to provide first insight into the earnings expectations of Macedonian students after graduation from university and to fill in the gap in the empirical literature.

This paper is organized as follows. Section 2 explores the literature related to the wage expectations of students, whereas Section 3 discusses data and used methodology. Section 4 presents and discusses results and Section 5 concludes the paper.

\section{Literature Review}

The decision on whether a person will choose to continue his/her education depends on its' perceived costs and benefits (Mazza and Hartog, 2011). However, there are only few studies that try to explain how expectations are formed and what the major determinants that affect expectations are. Across the scarce studies in this area, the following factors are commonly found to affect student's expectations about future earnings: the socioeconomic background of the student, gender, field of study, academic performance, age of a student, and sources of information (Wolter, 2000; Brunello et al., 2001; Wolter and Zbinden, 2001; Webbink and Hartog, 2004). We proceed by examining each of these factors separately. 


\section{Socioeconomic Background}

Most studies focus on the parents' education and income as a main socioeconomic factor that influences earnings expectations of students (Williams and Gordon, 1981; Webbink and Hartog, 2004; Delaney et al., 2011). Parental educational background is thought to influence student's expectations on at least two levels: (i) information on earnings from educated parents is of better quality, (ii) students who have well educated parents can rely on their parents' personal networks for finding a job after graduation, and hence have higher earnings (and job) expectations. Delaney et al. (2011) using data from seven Irish universities found out that parental education has a significant and positive effect on short-run and long-run earnings expectations. This however is not in line with the results of work by Betts (1996), Wolter (2000) and Wolter and Zbinden (2001). In particular, Betts (1996) conducting a survey among 1,000 undergraduates from the University of California found no strong effect between parental education and students' earnings estimation. This is confirmed by Wolter (2000) and Wolter and Zbinden (2001). Wolter (2000) used a different approach: imagining different scenarios students were asked to predict their own future earnings, as well as the earnings of an average person with similar characteristics. In this study, as well as in the study of Wolter and Zbinden (2001), parental education proved to be insignificant.

Different results appear when researchers examine the influence of the mother's and father's education on the students' earnings expectations separately. Brunello et al. (2001), in the study based on a survey conducted in 50 universities across ten European countries, found that having a mother with a university degree leads to a 3.3 percent increase in expected earnings right after graduation, and almost 4 percent, 10 years after entering labor market. In the same study the father's education was found not to be statistically significant. This was confirmed in another study of Brunello et al. (2004).

The results are consistent when researchers examine the influence of parental income on students' earnings expectations: earnings expectations are higher 
when parental income is higher (Betts, 1996; Varga, 2001; Webbink and Hartog, 2004; Jerrim, 2008). Jerrim (2008) and Webbink and Hartog (2004) agree that students from high-income families expect higher earnings in order to maintain high living standard and that their expectations are based on the income of the people around them. Webbink and Hartog (2004) argued that this result may be an important factor in explaining increased participation in extended education for students from wealthy backgrounds.

\section{Gender}

Researchers in many academic disciplines recognize the existence of an earnings gap between males and females (Filippin and Ichino, 2003; Chevalier 2004; Avlijaš et al., 2013) which is thought to affect earnings expectations for different genders: knowing the actual gender pay gap, students expect lower earnings for females. According to Chevalier (2004), women are still paid between 20 percent and 40 percent less than men despite the introduction of equal opportunity legislations. He argued that part of the existence of the gender earnings gap is explained by gender differences in educational and career choices, as well as the gender differences in expectations, but there is still a large part that is left unexplained. A study by Avlijaš et al. (2013) shows that the gender earnings gap in Macedonia in the period 2008-2011, on average, was 13.4 percent. When the gap is adjusted for the differences in personal characteristics, it increases to 17.5 percent, meaning that female workers have better labor market characteristics than their male counterparts.

According to several studies, women do expect to earn less than men (Carvajal et al., 2000; Wolter, 2000; Filippin and Ichino, 2003; Botelho and Pinto, 2004; Webbink and Hartog, 2004; Mazza and Hartog, 2011). Examining whether earnings expectations of students from Florida International University are realistic, Carvajal et al. (2000) found that female students expect and earn significantly less than male students. This is confirmed by Webbink and Hartog 
(2004) when using Dutch panel data. These authors examined the accuracy of students' prediction of their future earnings and found that female students expect to earn 5 percent less than males. This expectation of female students is very close to the actual gender earnings gap in Netherlands of 6 percent in favor of men, as assessed by Webbink and Hartog (2004). Botelho and Pinto (2004) and Filippin and Ichino (2003) agree that even though females expect lower earnings than males, they prove to be more realistic in their expectations.

\section{Age}

Most of the reviewed studies have examined the influence of students' age over their earnings expectations (Dominitz and Manski, 1994; Betts, 1996; Brunello et al., 2001; Wolter and Zbinden, 2001; Botelho and Pinto, 2004; Brunello et al., 2004). Dominitz and Manski (1994) found that earnings expectations are quite similar between junior and senior students. Opposite to this, several authors (Betts, 1996; Brunello et al., 2001; Wolter and Zbinden, 2001; Botelho and Pinto, 2004; Brunello et al., 2004; Borrego and Medina, 2010) agree that senior students expect lower earnings than junior students. Brunello et al. (2004) provide three possible explanations for such a result: (i) formation of earnings expectations improves as students approach graduation and become more realistic about their future earnings, (ii) senior students take questionnaires more seriously and/or (iii) students are taking future positive inflation and productivity growth into consideration.

\section{Field of Study}

Webbink and Hartog (2004) found that students in law, economics, health and technical studies expect to earn more than their colleagues from social sciences, while students in languages expect the same earnings as students in social studies. On the other hand, Brunello et al. (2001) found that students in Science 
and Engineering have higher expectations than students in Humanities or other disciplines, which is also confirmed by the studies of Jerrim (2008) and Borrego and Medina (2010). According to Jerrim (2008), the higher (and unrealistic) earnings expectations of the Science students are reflecting the difficulty of their chosen subject and the respective anticipation of a higher reward.

\section{Academic Performance}

The role of ability is in the center of discussion in the schooling behavior literature, but very few studies examined the relationship between ability and earnings expectations. Manski (1993) points out that young people use their ability to form their expectations, and that school choice depends on it. Several authors (Carvajal et al., 2000; Wolter and Zbinden, 2001; Brunello et al., 2004; Jerrim, 2008) include an academic performance variable in order to test if there is any correlation between students' earnings expectations and their performance in college. Academic performance is measured through students' perception of their ability compared to other students. The results are consistent: students who perceived themselves as high performers have higher expected university earnings.

\section{Sources of Information}

The source of information about earnings prevalent in the labor market can also affect earnings expectations. Adding this variable into regression, Brunello et al. (2001) and Wolter and Zbinden (2001) found opposite results. The former study found that when information is personal or collected from the daily and weekly press then this variable is significant and positively affects students' earnings expectations. On the other hand, the latter study finds that students with no specific information on earnings have significantly higher expectations than the rest. 


\section{Other Findings}

Several authors examined other influences over students' earnings expectations. Anchor et al. (2011) comparing students' expectations in England and Czech Republic found that students who experience higher costs for their studies (in terms of foregone earnings and tuition fees) tend to have higher earnings expectations in order to compensate those costs. McMahon and Wagner (1981) and Jerrim (2008) examined the influence of ethnicity over students' earnings expectations. Both studies find that students from minority backgrounds expect higher starting earnings and tend to be more optimistic about their future earning potential. Epple and Romano (1998) suggest that private schools attract students with higher quality and therefore these students expect higher earnings than their colleagues.

In summary, when deciding on the amount of education to "consume", individuals compare different options and choose the one with the highest return. Therefore, expectations for future earnings are a major determinant that influences schooling decision. The review of the relevant literature revealed the complexity of expectations' formation and that expectations are mostly influenced by the students' personal characteristics (age, gender), their socioeconomic background (education and income of their parents), field of study, academic performance, sources of information on earnings, etc.

\section{Methodology and Data}

Several authors using different approaches have tried to examine which determinants influence students' earnings expectations (Wolter ans Zbiden, 2001; Brunello et al., 2001, 2004; Webbink and Hartog, 2004; Anchor et al., 2011). Our study is based on the methodology used in the work of Brunello et al. (2001), which is originally based on a method for estimation of private return on 
education known as Mincer's method. Mincer (1974) was one of the first authors who applied the concept of human capital for empirical estimation of the returns on education. In the Mincerian equation, a dependent variable is the earnings of an individual, which is presented in a logarithmic form. Brunello et al. (2001) estimated linear regression in which the dependent variable is a logarithm of students' expected earnings regressed on a set of independent variables.

Data used in our study on earnings expectations of Macedonian students were collected through a survey conducted in 11 faculties (schools) belonging to three universities in Macedonia (one state and two private). The share of these three universities in the total enrollments in the universities across Macedonia is 80 percent. Appendix A presents details on the universities participating in the study.

The questionnaire used in the work of Brunello et al. $(2001,2004)$ was adapted for the purpose of our study, taking into consideration the specific country context and our research questions. We asked students of their earnings expectations under two different scenarios: i) expected monthly net earnings right after university graduation, and ii) expected monthly net earnings 10 years after graduation. The distributed questionnaire was in Macedonian, while here we present the questionnaire in English (see Appendix B).

In order to collect relevant answers about expected earnings after graduation, students got to choose from several intervals to which they thought that their future monthly net earnings belong. We used interval amounts that are commonly used by the State Statistical Office. The ordered variable was then transformed into a continuous variable by calculating the mean from each interval. We then applied linear regression, which is defined as:

$$
\ln W_{i}=\alpha+\beta_{i} X_{i}+\varepsilon_{i}
$$

where:

$\alpha=$ constant;

$W_{i, c}=$ expected net earnings of individual I; 
$\beta_{i}=$ vector of parameters to be estimated;

$X_{i}=$ vector of parameters, assumed that have an influence on earnings

expectations; and

$\varepsilon_{i}=$ error, assumed to be well-behaved.

Table 1 examines variables used in our study, $X_{i}$.

The questionnaire was distributed among undergraduate students in the spring semester of the academic year 2012/2013. Different fields of study were selected randomly and students were asked to fill in the questionnaire during the first minutes of a lecture. This method delivered a 100-percent response rate and 496 questionnaires were returned.

In this type of research, there is concern that the so-called anchoring effect might influence the results. Anchoring effect is considered to be one of the most robust psychological phenomena, found in many areas of human judgment and decision making (McElroy and Dowd, 2007). When answering ambiguous questions most people start with available value, and make final adjustment from this value. Anchoring effect occurs when this adjustment is insufficient to compensate for the starting value/answer (Kudryavtsev and Cohen, 2010). However, since the results in the area of earnings expectations are consistent across countries and researchers, we exclude the possibility of anchoring effect in this research.

Tables C1 and C2 in Appendix C present in detail descriptive statistics for the sample. The average age of the students in the sample is around 21 years. At the time of the survey, 59 percent of the students were in their first year of study, while others were in their last year of study. The share of female respondents was slightly higher: 56 percent compared to 44 percent of males. The majority of the respondents ( 85 percent) reported Macedonian ethnicity, while the others were mainly Albanian and Turkish. 
Table 1: Description of Variables

\begin{tabular}{|c|c|c|}
\hline & $\begin{array}{l}\text { Earnings expectation with a } \\
\text { university degree }\end{array}$ & Continuous variable \\
\hline & $\begin{array}{l}\text { Earnings expectation with a } \\
\text { university degree } 10 \text { years after } \\
\text { graduation }\end{array}$ & Continuous variable \\
\hline & Year of study & Dummy 1 =juniors; $0=$ seniors \\
\hline & Type of school & Dummy $1=$ private; $0=$ state \\
\hline \multirow{4}{*}{ 荙柔 } & Business and Economy & Dummy $1=$ yes; $0=$ otherwise \\
\hline & Engineering & Dummy $1=$ yes; $0=$ otherwise \\
\hline & Mathematics & Dummy $1=$ yes; $0=$ otherwise \\
\hline & Medicine & Dummy $1=$ yes; $0=$ otherwise \\
\hline & $\begin{array}{l}\text { Father holding university degree } \\
\text { or Master/PhD }\end{array}$ & Dummy $1=$ yes; $0=$ otherwise \\
\hline & $\begin{array}{l}\text { Mother holding university degree } \\
\text { or Master/PhD }\end{array}$ & Dummy $1=y e s ; 0=$ otherwise \\
\hline & Same field as father & Dummy $1=$ yes; $0=$ no \\
\hline & Same field as mother & Dummy $1=$ yes; $0=$ no \\
\hline & Repeaters & Dummy $1=$ yes; $0=$ no \\
\hline & \multirow{6}{*}{ Academic performance } & Ordered variable on a scale 1 to 5 \\
\hline & & $1=$ very good \\
\hline & & $2=\operatorname{good}$ \\
\hline & & $3=$ average \\
\hline & & $4=$ poor \\
\hline & & $5=$ very poor \\
\hline & \multirow{2}{*}{ Employment in family business } & Dummy \\
\hline & & $1=$ yes; $0=$ no/my family doesn't have household business \\
\hline & \multirow{6}{*}{ Employability } & Ordered variable on a scale 1 to 5 \\
\hline & & $1=$ very good \\
\hline & & $2=\operatorname{good}$ \\
\hline & & $3=$ average \\
\hline & & $4=$ poor \\
\hline & & $5=$ very poor \\
\hline & Expected country of employment & Dummy $1=$ Macedonia; $0=$ other country \\
\hline & Regular job during studies & Dummy $1=$ yes; $0=$ no \\
\hline \multirow{7}{*}{ 总 } & W1 & Dummy $1=$ career centre; $0=$ otherwise \\
\hline & W2 & Dummy $1=$ daily $/$ weekly press $0=$ otherwise \\
\hline & W3 & Dummy 1 =personal communications $0=$ otherwise \\
\hline & W4 & Dummy $1=$ never; $0=$ otherwise \\
\hline & Costs & Continuous variable \\
\hline & Gender & Dummy $1=$ females; $0=$ males \\
\hline & Ethnicity & Dummy $1=$ Macedonian; $0=$ other \\
\hline
\end{tabular}


Less than half (43 percent) of the students were studying in private universities. About 43 percent of the respondents belonged to households where fathers held a university degree or a master/ $\mathrm{PhD}$, and 44 percent of the respondents belonged to households where mothers held a university degree or a master/ PhD. A small portion of students was enrolled in the same field of study as their parents, 19 percent were in the same field of study as their fathers, while 13 percent were in the same field of study as their mothers. A gender analysis shows that males are more likely to follow academic choices of their fathers (9.6 percent) than academic choices of their mothers (3.6 percent). Students in Macedonia expect their average starting earnings after graduation to be 24,085 denars (approximately 390 euros), and 36,150 denars (588 euros) 10 years after graduation. Students expect that their earnings after 10 years on the job, on average, will be 50 percent higher if they hold a university degree, and 20 percent higher if they have finished only secondary education.

Males have higher earnings expectations than females. After graduation from university, males expect to earn on average 15 percent higher earnings than females. This gap increases to 17 percent after 10 years in the labor market. Have they completed only secondary education, males would have expected to receive 25 percent higher earnings than females immediately after completing the education, but this gap is decreasing to 9 percent after 10 years in the labor market. Data also show that students from Macedonian ethnicity, on average, expect lower earnings than their peers from other ethnicities after graduation from secondary school or university. They expect this gap to decline in 10 years, and even to become reverse for those with completed university education.

Two thirds of the students heard about earnings prospects through personal communication with family, friends, etc., 12 percent were informed by daily/ weekly press and 7 percent by university career centers. When asked about chances for finding an appropriate job with completed tertiary education, 39.8 percent of the respondents think that they have good chances of getting an appropriate job after graduation. About 35 percent of females and 27 percent of males think that 
they have average chances of finding an appropriate job after graduation, while 19 percent males and 14 percent females think that they have very good chances of finding an appropriate job. A very small share of respondents (9 percent) hold a regular job while studying and they work on average 19 hours per week. About one third of the students expect to work in their family businesses. Two thirds of the students expect to find a job in Macedonia, while 34 percent expect to work outside Macedonia, mostly in Germany.

\section{Results}

Before we proceed with the estimation of Equation (1) we run a Chow test to check the structural stability of the regression i.e., to see whether the same regression model is appropriate to estimate the relationship between the dependent and the explanatory variables for junior (1st year) and senior (last year) students, given that the findings from other studies point to a difference in the earnings expectations of these two groups of students (see Section 3). Results presented in Appendix E show no structural differences between these two subsets (juniors and seniors) hence we can run the regression jointly. We also run Breusch-Pagan test which is designed to show any linear form of heteroskedasticity. Results presented in Appendix F show that the model does not suffer heteroscedasticity. Moreover, Appendix G confirms the normality of residuals. We therefore proceed by estimating regression (1).

The results from the estimated Equation (1) are presented in Appendix D. Data are presented for the dependent variable: i) earnings expectations after graduation from university (column 1) and ii) earnings expectations 10 years after graduation (column 2). We proceed by interpreting the results and examining factors that significantly influence earnings expectations of Macedonian students.

The coefficient of determination for the first equation is about 22 percent, meaning that 22 percent of the variability in the earnings expectations of students after graduation is explained by the independent variables/regressors. 
The coefficient of determination for the second equation is about 26 percent, meaning that 26 percent of the variability in the earnings expectations of students 10 years after graduation is explained by the independent variables/ regressors. Coefficients are jointly significant and coefficients have the expected signs. As Table D1 (Appendix D) shows, following variables are found to have a significant influence on the earnings expectations of students: year of study (juniors vs. seniors), field of study, father's education, sources of information, country of employment, perceived employability, holding a regular job during studies, gender and ethnicity.

In Macedonia, students who belong to households where the father has a university degree or a master $/ \mathrm{PhD}$, expect to earn 10 percent more than their peers at the labor market entry and 15.6 percent more 10 years later. In EU countries having a father with a university degree is not statistically significant (for instance, see Brunello et al., 2001). Our study shows that in Macedonia there is no effect of the mother's education on the earnings expectation of students. Furthermore, in Macedonia as in EU, there is no statistically significant correlation between expected earnings and the study in the same field as parents.

We find that female students in Macedonia, as in most European countries, expect to earn less than their male colleagues, 10 percent less if they hold a university degree. This gap increases to 20 percent after 10 years on the job with university degree.

Similar to the findings of several authors from Europe (Brunello et al., 2001; Wolter and Zbinden, 2001; Borrego and Medina, 2010), junior students expect to earn more than senior students. In Macedonia juniors expect to earn 14 percent more than senior students at the labor market entry, and 9.5 percent more 10 years later. Section 3 provides several possible explanations for the greater optimism of the junior students.

When examining the relation between students' earnings expectations and chosen field of study, we found that Medicine students at the entry into the labor 
market expect to earn 25 percent less than Engineering students. After 10 years on the job, this percentage slightly decreases to 24 percent. The coefficients for the other fields of study are insignificant. This result is in line with the work of Brunello et al. (2001).

Depending on how students are informed about earnings in their field of study, their earnings expectations might vary. In Macedonia, students who have gathered information on future earnings at the university career centers expect to earn 25 percent more at the beginning of their careers than students who do not have such information. Students who inform themselves from daily or weekly press expect to earn 15 percent more than students with no information on future earnings. These results are opposite to the results from the study of Wolter and Zbinden (2001).

Students from Macedonian ethnicity expect to have 10 percent lower earnings than their colleagues from other ethnicities at the entry into the labor market. Lower expectations of ethnic Macedonians can be related to the policy of equal representation of ethnic minorities (under the Ohrid Framework Agreement), as well as the lower relative supply of workers from ethnic minorities who hold a university degree. Coefficients on the ethnicity after 10 years on the job are not statistically significant. Although Epple and Romano (1998) suggest that students from private universities expect higher future earnings, we have not found a correlation between the type of school (private vs. state) and students' earnings expectations.

Holding a regular job while studying can influence students' earnings expectations in at least two ways: (i) students who work during their studies have insideinformation about earnings and the labor market and (ii) they take their work experience into consideration and therefore expect higher earnings. In Macedonia, students who hold a regular job during their studies expect to earn 13.7 percent more than students who do not work. 
Because of the evidenced brain drain in Macedonia, we asked students about the country of their expected employment. Students who expect to work in Macedonia have 17 percent and 22 percent lower earnings expectations than students who expect to work abroad at the entry into labor market and 10 years after graduation, respectively.

Opposite to the results from the work of Anchor et al. (2011) we have not found any correlation between costs of studies and students earnings expectations.

\section{Conclusion}

The aim of this paper was to fill the gap in the empirical literature on the factors influencing earnings expectations of Macedonian students. In addition, we have put the results into comparative perspective with the EU students.

We employed similar empirical approach as the one used by Brunello et al. (2001, 2004) in which we regress the i) expected future earnings right after university graduation and ii) expected future earnings 10 years after graduation, on a set of variables: characteristics of the individual, socio-economic background, field of study, year of study, academic performance, sources of information for future earnings. We collected data through a questionnaire administered to junior and senior students at three universities (one state university and two private ones) in Macedonia.

Our findings show that Macedonian students form their earnings expectations in a similar vein as their European counterparts. In other words, their expected university earnings are significantly correlated with their father's education, their year of study, sources of information on earnings in the labor market, gender, ethnicity, holding a regular job during studies, perceived employability, field of study, and country of future employment. 
The results show that students who have a more educated father expect to earn more than their peers, whereas the mother's education does not exert any significant effect on the earnings expectations. As in most studies, we find that females expect to earn less, with the expected gap increasing through time. Junior students are more optimistic about their earnings potential relative to their senior peers. Students who are more informed about the earnings prospects tend to have higher expectations for their wages. We also find evidence for the role of ethnicity such that students from Macedonian ethnicity on average have lower expectations. Students who have worked while studying have higher expectations compared to their colleagues, either due to having better information on actual earnings, or because of the presumed value of the work experience for future earnings.

These findings show a strong effect of socio-economic background of a student and his/her demographic characteristics on future earnings expectations. Part of the expectations though is formed by the availability of information and emigration intentions of students. The role of the authorities, in this respect, should be to improve the provision of information on potential jobs and earnings to the secondary and tertiary education students. This will assist students in making more rational schooling decisions.

We suggest that a future work in this area includes students from all countries in the Western Balkans region, as to produce comparative results within the region, but also with the EU countries. 


\section{Appendix A}

\begin{tabular}{|c|c|c|}
\hline University & $\begin{array}{l}\text { Type of } \\
\text { institution }\end{array}$ & Faculty \\
\hline \multirow{3}{*}{$\begin{array}{l}\text { American College } \\
\text { Skopje }\end{array}$} & \multirow{3}{*}{ Private } & 1 School of Business Economics and Management \\
\hline & & $\begin{array}{l}2 \text { School of Computer Science and Information } \\
\text { Technology }\end{array}$ \\
\hline & & 3 School of Architecture and Design \\
\hline \multirow{7}{*}{$\begin{array}{l}\text { St. Cyril and Methodius } \\
\text { Skopje }\end{array}$} & \multirow{7}{*}{ State } & 4 Faculty of Economics \\
\hline & & 5 Faculty of Civil Engineering \\
\hline & & 6 Faculty of Agriculture and Food \\
\hline & & 7 Faculty of Natural Sciences and Mathematics \\
\hline & & 8 Faculty of Architecture \\
\hline & & 9 Faculty of Electrical Engineering \\
\hline & & 10 Faculty of Medicine \\
\hline $\begin{array}{l}\text { European University } \\
\text { Skopje }\end{array}$ & Private & 11 Faculty of Economics \\
\hline
\end{tabular}




\section{Appendix B}

This is a survey on the income prospects of Macedonian students. We would kindly ask you to answer the following questions. It should not take more than 10 minutes. Thank you very much for your cooperation.

1. What is your field of study?
(1) Business studies
(4) Law, Political science
(2) Economics
(5) Medicine
(3) Natural sciences, Engineering
(6) Other

2. What level of schooling did your parents achieve (final degree reached)?

\section{Father}

(1) No formal degree

(2) Apprenticeship training

(3) Elementary school

(4) High school degree

(5) Higher education

(6) University degree

(7) Master/PhD

(8) Don't know
Mother

(1) No formal degree

(2) Apprenticeship training

(3) Elementary school

(4) High school degree

(5) Higher education

(6) University degree

(7) Master/PhD

(8) Don't know

3. If your father holds a university degree, do you study the same field as your father?

(1) Yes

(2) No

4. If your mother holds a university degree, do you study the same field as your
father?
(1) Yes
(2) No

5. When did you start your university studies? In 20

6. How many years are formally required to obtain a first degree? years.

7. When do you expect to finish your studies with a first degree?
(1) 2013
(2) 2014
(3) 2015
(4) 2016
(5) 2017
(6) later 
8. Please mark your personal academic performance (relative to your colleagues') on the following scale.

very good

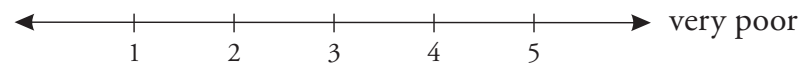

9. Have you ever read/heard reports about income prospects of university graduates and where? (multiple answers are possible)?

(1) in the university career centers

(2) in the daily/weekly press

(3) personal communication (e.g. friends, relatives, colleagues ...)

(4) never

10. What do you expect to earn right after finishing your degree (first degree possible at your university) at your first job?
(1) Less than 5,000 denars
(6) Between 16,001 and 20,000
(2) Between 5,001 and 8,000
(7) Between 20,001 and 25,000
(3) Between 8,001 and 10,000
(8) Between 25,001 and 30,000
(4) Between 10,001 and 12,000
(9) Between 30,001 and 40,000
(5) Between 12,001 and 16,000
(10) More than 40,001 denars

11. What would you have earned if you had started working right after finishing high school? (State the approximate amount per month)

12. Please tell us your expectations about wage growth:

a) Having finished my university degree, after 10 years on the job I'll earn percent more than in the first year.

b) Not having acquired a university degree (i.e. had I started right after high school), after 10 years on the job I will earn percent more than in the first year. 
13. Setting to 100 your wage 1 year after graduation, how much do you think would be earned by a student with the same characteristics as yours but of the other gender?

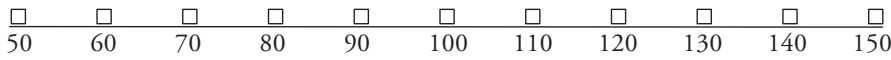

14. Setting to 100 your wage 10 year after graduation, how much do you think would be earned by a student with the same characteristics as yours but of the other gender?

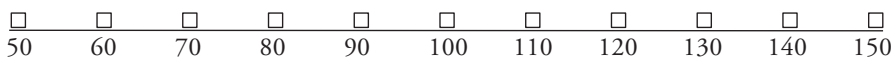

15. If your answer in 13 and/or 14 was different from 100: why? (Multiple choices allowed)

(1) Characteristics and aptitudes differ between males and females.

(2) Different distribution of household duties.

(3) Employers expect different characteristics between males and females.

(4) Employers have specific views on the differences in the characteristics of males and females, and the distribution of household duties.

16. Setting to 100 your wage 1 year after graduation, how much do you think would be earned by a student with the same characteristics as yours but of another ethnicity?

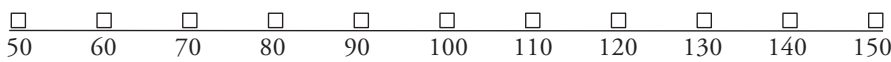

17. Setting to 100 your wage 10 years after graduation, how much do you think would be earned by a student with the same characteristics as yours but of another ethnicity?

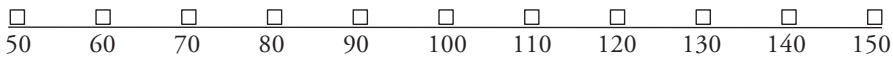


18. After graduation do you expect to work in a household business?
(1) Yes
(2) No
(3) My family doesn't own a business

19. Where do you expect to find a job after graduation from university?
(1) Macedonia (name city)
(2) Abroad (name country)

20. How do you consider your chances of getting an appropriate job after graduating?
(1) very poor
(2) poor
(3) average
(4) good
(5) very good

21. Are these chances better or worse compared to having only high school education? The prospects after finishing university are:
(1) much worse
(2) worse
(3) same
(4) better
(5) much better

22. Do you hold a regular job during your studies? (1) yes, hours a week (2) no

23. How much do you spend per year of your study in directly university-related expenses (e.g. tuition, books)?

24. What were the determinants for your choice of study? Please rank the following items between 1 (most important) and 5(least important).

- Proximity to my home town

- Academic reputation/standard

- Costs (e.g. housing, tuition...)

- Income and job prospects

- Interest in the subject 
Marija Andonova and Nikica Mojsoska-Blazevski

Factors Influencing the Earnings Expectations among Macedonian Students: A Comparative Perspective with the EU Students

Croatian Economic Survey : Vol. 17 : No. 1 : June 2015 : pp. 71-110

25. Year of birth

26. Gender.

(1) male

(2) female

27. Ethnicity

28. Place of birth (city, state) 


\section{Appendix C}

Table C1: Descriptive Statistics

\begin{tabular}{|c|c|c|c|c|c|}
\hline \multicolumn{6}{|c|}{ Descriptive Statistics } \\
\hline & $\mathbf{N}$ & Minimum & Maximum & Mean & $\begin{array}{c}\text { Std. } \\
\text { Deviation }\end{array}$ \\
\hline Year of study & 496 & 0 & 1 & 0.59 & 0.492 \\
\hline Type of school & 496 & 0 & 1 & 0.43 & 0.495 \\
\hline \multicolumn{6}{|l|}{ Field of study } \\
\hline Business & 496 & 0 & 1 & 0.20 & 0.399 \\
\hline Economy & 496 & 0 & 1 & 0.09 & 0.285 \\
\hline $\begin{array}{l}\text { Computer Science and } \\
\text { Information technology }\end{array}$ & 496 & 0 & 1 & 0.05 & 0.210 \\
\hline Mathematics & 496 & 0 & 1 & 0.07 & 0.249 \\
\hline Civil Engineering & 496 & 0 & 1 & 0.16 & 0.364 \\
\hline Architecture and Design & 496 & 0 & 1 & 0.19 & 0.389 \\
\hline Medicine & 496 & 0 & 1 & 0.07 & 0.253 \\
\hline Electrical Engineering & 496 & 0 & 1 & 0.02 & 0.147 \\
\hline Agriculture and food & 496 & 0 & 1 & 0.17 & 0.374 \\
\hline Father's education & 496 & 0 & 7 & 5.02 & 1.236 \\
\hline no formal degree & 496 & 0 & 1 & 0.00 & 0.045 \\
\hline apprenticeship training & 496 & 0 & 1 & 0.01 & 0.090 \\
\hline primary education & 496 & 0 & 1 & 0.02 & 0.126 \\
\hline secondary education & 496 & 0 & 1 & 0.36 & 0.482 \\
\hline higher education & 496 & 0 & 1 & 0.17 & 0.375 \\
\hline university degree & 496 & 0 & 1 & 0.34 & 0.474 \\
\hline Master/PhD & 496 & 0 & 1 & 0.09 & 0.282 \\
\hline don't know & 496 & 0 & 1 & 0.01 & 0.109 \\
\hline $\begin{array}{l}\text { Father holding university } \\
\text { degree or Master/PhD }\end{array}$ & 496 & 0 & 1 & 0.43 & 0.495 \\
\hline Mother's education & 496 & 0 & 7 & 4.96 & 1.306 \\
\hline no formal degree & 496 & 0 & 1 & 0.01 & 0.078 \\
\hline apprenticeship training & 496 & 0 & 1 & 0.00 & 0.063 \\
\hline primary education & 496 & 0 & 1 & 0.03 & 0.182 \\
\hline secondary education & 496 & 0 & 1 & 0.35 & 0.477 \\
\hline higher education & 496 & 0 & 1 & 0.15 & 0.359 \\
\hline university degree & 496 & 0 & 1 & 0.37 & 0.484 \\
\hline Master/PhD & 496 & 0 & 1 & 0.06 & 0.246 \\
\hline don't know & 496 & 0 & 1 & 0.02 & 0.134 \\
\hline $\begin{array}{l}\text { Mother holding university } \\
\text { degree or Master/PhD }\end{array}$ & 496 & 0 & 1 & 0.44 & 0.497 \\
\hline Same field as father & 496 & 0 & 1 & 0.19 & 0.394 \\
\hline Same field as mother & 496 & 0 & 1 & 0.13 & 0.338 \\
\hline Repeaters & 496 & 0 & 1 & 0.33 & 0.471 \\
\hline Academic performance & 493 & 1 & 5 & 2.41 & 1.102 \\
\hline
\end{tabular}




\begin{tabular}{|c|c|c|c|c|c|}
\hline Earnings information & & & & & \\
\hline WI1 & 491 & 0 & 1 & 0.07 & 0.258 \\
\hline WI2 & 491 & 0 & 1 & 0.12 & 0.328 \\
\hline WI3 & 491 & 0 & 1 & 0.67 & 0.471 \\
\hline WI4 & 491 & 0 & 1 & 0.14 & 0.344 \\
\hline $\begin{array}{l}\text { University monthly net } \\
\text { earnings }\end{array}$ & 496 & 5000 & 45,000 & $24,085.69$ & $10,865.673$ \\
\hline $\begin{array}{l}\text { High school monthly net } \\
\text { earnings }\end{array}$ & 489 & 0 & 60,000 & $11,818.00$ & 6697,477 \\
\hline $\begin{array}{l}\text { Graduation earnings } \\
\text { after } 10 \text { years, } \%\end{array}$ & 491 & 0 & 400 & 49.35 & 43.556 \\
\hline $\begin{array}{l}\text { High school } \\
\text { earnings after } 10 \mathrm{y}, \%\end{array}$ & 490 & 0 & 322 & 19.76 & 28.263 \\
\hline Opposite gender & 491 & 5 & 160 & 100.10 & 17.794 \\
\hline Opposite gender 10 & 491 & 50 & 150 & 112.51 & 22.334 \\
\hline Other ethnicity & 491 & 50 & 150 & 101.96 & 15.234 \\
\hline Other ethnicity 10 & 491 & 10 & 150 & 108.53 & 21.307 \\
\hline Family business & 490 & 0 & 1 & 0.31 & 0.462 \\
\hline $\begin{array}{l}\text { Where do you expect to find } \\
\text { a job after graduation from } \\
\text { university? }\end{array}$ & 488 & 0 & 1 & 0.66 & 0.476 \\
\hline Employability & 491 & 1 & 5 & 3.55 & 0.992 \\
\hline Regular job & 491 & 0 & 1 & 0.09 & 0.292 \\
\hline Working hours & 34 & 4 & 50 & 19.82 & 14.147 \\
\hline Costs & 488 & 6500 & 360,000 & $92,133.48$ & $64,860.180$ \\
\hline Year of birth & 491 & 1968 & 1995 & 1991.73 & 2.285 \\
\hline Gender & 490 & 0 & 1 & 0.56 & 0.497 \\
\hline Ethnicity & 484 & 0 & 1 & 0.85 & 0.360 \\
\hline
\end{tabular}

Table C2: Descriptive Statistics by Gender

\begin{tabular}{|c|c|c|}
\hline Variable & $\begin{array}{c}\% \\
\text { male } \\
\end{array}$ & $\begin{array}{c}\% \\
\text { female }\end{array}$ \\
\hline \multicolumn{3}{|l|}{ Field of study } \\
\hline Business & 8.6 & 11.2 \\
\hline Economy & 1.8 & 6.9 \\
\hline IT & 4.1 & 0.6 \\
\hline Mathematics & 1.6 & 5.1 \\
\hline Civil engineering & 9.0 & 6.9 \\
\hline Architecture & 7.8 & 10.2 \\
\hline Medicine & 1.8 & 5.1 \\
\hline Electrical engineering & 1.4 & 0.8 \\
\hline Agriculture and food & 8.2 & 8.8 \\
\hline \multicolumn{3}{|l|}{ Parent's education } \\
\hline Father & & \\
\hline
\end{tabular}




\begin{tabular}{|c|c|c|}
\hline don't know & 0.4 & 0.8 \\
\hline no formal degree & 0.2 & 0.0 \\
\hline apprenticeship training & 0.8 & 0.0 \\
\hline primary education & 0.4 & 1.2 \\
\hline secondary education & 15.5 & 21 \\
\hline higher education & 8.0 & 9.2 \\
\hline university degree & 13.3 & 20.4 \\
\hline Master/PhD & 5.7 & 3.1 \\
\hline \multicolumn{3}{|l|}{ Mother } \\
\hline don't know & 0.8 & 1.0 \\
\hline no formal degree & 0.2 & 0.4 \\
\hline apprenticeship training & 0.2 & 0.2 \\
\hline primary education & 1.6 & 1.8 \\
\hline secondary education & 14.7 & 20.2 \\
\hline higher education & 8.0 & 7.1 \\
\hline university degree & 16.3 & 20.8 \\
\hline Master/PhD & 2.4 & 4.1 \\
\hline \multicolumn{3}{|l|}{ Same education as parent } \\
\hline same field as father & 9.6 & 9.8 \\
\hline same field as mother & 3.9 & 9.4 \\
\hline \multicolumn{3}{|l|}{ Year of study } \\
\hline junior & 27.1 & 31.8 \\
\hline senior & 17.1 & 23.9 \\
\hline \multicolumn{3}{|c|}{ Relative academic performance } \\
\hline very poor & 9.7 & 16.8 \\
\hline poor & 10.5 & 14.2 \\
\hline average & 15.7 & 16.4 \\
\hline good & 6.8 & 7.2 \\
\hline very good & 1.2 & 1.4 \\
\hline Repeaters & 16.3 & 16.7 \\
\hline Regular job during studies & 31 & 15 \\
\hline \multicolumn{3}{|l|}{ Perceived employability } \\
\hline very poor & 1.8 & 1.6 \\
\hline poor & 5.7 & 3.9 \\
\hline average & 11.8 & 19.6 \\
\hline good & 16.3 & 23.1 \\
\hline very good & 8.6 & 7.6 \\
\hline \multicolumn{3}{|l|}{ Country of employment } \\
\hline Macedonia & 23.8 & 37.2 \\
\hline Family business & 16 & 14 \\
\hline Other country & 16 & 18.5 \\
\hline \multicolumn{3}{|l|}{ Ethnicity } \\
\hline Macedonian & 34.9 & 49.8 \\
\hline other & 9.1 & 6.2 \\
\hline Observations & $44.3 \%$ & $55.7 \%$ \\
\hline
\end{tabular}




\section{Appendix D}

Table D1: Expected Graduation and High School Earnings and Expected Earnings Gain 10 Years after Labor Market Entry

\begin{tabular}{|c|c|c|}
\hline & $\begin{array}{c}\text { University earnings } \\
\beta\end{array}$ & $\begin{array}{c}\text { University earnings } 10 \\
\text { years after graduation } \\
\beta\end{array}$ \\
\hline Year of study (juniors $=1$ ) & $0.149^{* * *}$ & $0.095^{* *}$ \\
\hline Type of school (private $=1$ ) & 0.014 & -0.004 \\
\hline \multicolumn{3}{|l|}{$\begin{array}{l}\text { Field of study: reference category: } \\
\text { Engineering }\end{array}$} \\
\hline MATH & 0.013 & -0.117 \\
\hline Medicine & $-0.247^{* * *}$ & $-0.239^{* * *}$ \\
\hline Business and economy & -0.005 & 0.020 \\
\hline $\begin{array}{l}\text { Father holding university degree or } \\
\text { Master/PhD }\end{array}$ & $0.102^{* *}$ & $0.156^{* * *}$ \\
\hline $\begin{array}{l}\text { Mother holding university degree or } \\
\text { Master/PhD }\end{array}$ & 0.047 & 0.026 \\
\hline Same field as father & -0.043 & -0.044 \\
\hline Same field mother & 0.060 & 0.008 \\
\hline Repeaters & 0.014 & 0.005 \\
\hline Academic performance & -0.003 & -0.007 \\
\hline \multicolumn{3}{|l|}{$\begin{array}{l}\text { Earnings information (reference } \\
\text { category=never) }\end{array}$} \\
\hline WI1 (career centre $=1)$ & $0.251^{* * *}$ & $0.312^{* * *}$ \\
\hline WI2 (daily/weekly press=1) & $0.151^{* *}$ & $0.223^{* * *}$ \\
\hline WI3 (personal communication=1) & 0.011 & 0.057 \\
\hline Family business & -0.008 & -0.010 \\
\hline Country of employment & $-0.170^{* * *}$ & $-0.219^{* * *}$ \\
\hline Employability & $0.082^{* * *}$ & $0.131^{* * *}$ \\
\hline Regular job & $0.137^{*}$ & $0.127^{* *}$ \\
\hline Costs & 0.000 & 0.000 \\
\hline Gender $($ female $=1)$ & $-0.103^{* * *}$ & $-0.201^{* * *}$ \\
\hline Ethnicity (Macedonian=1) & $-0.106^{* *}$ & -0.052 \\
\hline
\end{tabular}

Note: ${ }^{* * *}$ and ${ }^{* * *}$ indicate significance at the 10,5 and $1 \%$ level, respectively. 


\section{Appendix E}

\section{Testing Structural Stability of the Regression}

\section{Hypothesis A: There are no structural differences between junior and senior students.}

$$
F_{\text {STAT }}=\frac{(a-b) / p}{b /(n-2 p)}
$$

and compared calculated number with critical values of F from statistical tables.

Parameters from equation (E.1) are defined as:

$a=$ residual sum of squares

$b=$ residual sum of squares between groups

$n=$ number of observations

$p=$ number of variables

Setting the level of significance $\alpha$ to 0.05 for all three regressions, $d f_{1}=22$ $\left(d f_{1}=\right.$ degrees of freedom of the numerator), $d f_{2}=\infty$ (since degrees of freedom for denominator is large number, we take infinity instead) critical values of $\mathrm{F}$ statistics for all three hypotheses is $F\left(\alpha, d f_{1}, d f_{2}\right)=F(0.05,22, \infty)=1.54$.

First we run the regression model ignoring the groups (to compute a).

\begin{tabular}{|c|c|c|c|c|c|c|}
\hline \multicolumn{7}{|c|}{ ANOVA } \\
\hline \multicolumn{2}{|c|}{ Model } & $\begin{array}{l}\text { Sum of } \\
\text { Squares }\end{array}$ & df & $\begin{array}{l}\text { Mean } \\
\text { Square }\end{array}$ & $\mathbf{F}$ & Sig. \\
\hline \multirow[t]{3}{*}{1} & Regression & 18.748 & 20 & 0.937 & 5.817 & 0.000 \\
\hline & Residual & 73.002 & 453 & 0.161 & & \\
\hline & Total & 91.750 & 473 & & & \\
\hline
\end{tabular}

After running the regression model ignoring the groups, we proceed by running the regression model on subsets (year of study). 


\begin{tabular}{|c|c|c|c|c|c|c|}
\hline \multicolumn{7}{|c|}{ Juniors ANOVA } \\
\hline \multicolumn{2}{|c|}{ Model } & $\begin{array}{l}\text { Sum of } \\
\text { Squares }\end{array}$ & df & $\begin{array}{l}\text { Mean } \\
\text { Square }\end{array}$ & $\mathbf{F}$ & Sig. \\
\hline \multirow[t]{3}{*}{1} & Regression & 13,134 & 20 &, 657 & 3,465 &, 000 \\
\hline & Residual & 48,709 & 257 &, 190 & & \\
\hline & Total & 61,843 & 277 & & & \\
\hline
\end{tabular}

\begin{tabular}{|c|c|c|c|c|c|c|}
\hline \multicolumn{7}{|c|}{ Seniors ANOVA } \\
\hline \multicolumn{2}{|c|}{ Model } & $\begin{array}{l}\text { Sum of } \\
\text { Squares }\end{array}$ & df & $\begin{array}{c}\text { Mean } \\
\text { Square }\end{array}$ & $\mathbf{F}$ & Sig. \\
\hline \multirow[t]{3}{*}{1} & Regression & 6,524 & 19 & ,343 & 2,980 &, 000 \\
\hline & Residual & 20,277 & 176 &, 115 & & \\
\hline & Total & 26,802 & 195 & & & \\
\hline
\end{tabular}

Since, $\mathrm{n}=474$, and $\mathrm{p}=22$, we can compute $F=\frac{(73.002-68.986) / 22}{68.986 / 432}=1.14$.

The results show that there are no structural differences between junior and senior students.

Since, $F=1.14<1.54=F(0.05,22, \infty)$ we conclude that there is no evidence to reject the null hypothesis. There is no structural instability between these two subsets (juniors and seniors) and the regression model is appropriately modelled. 


\section{Appendix F}

\section{Testing Homoskedasticity in SPSS}

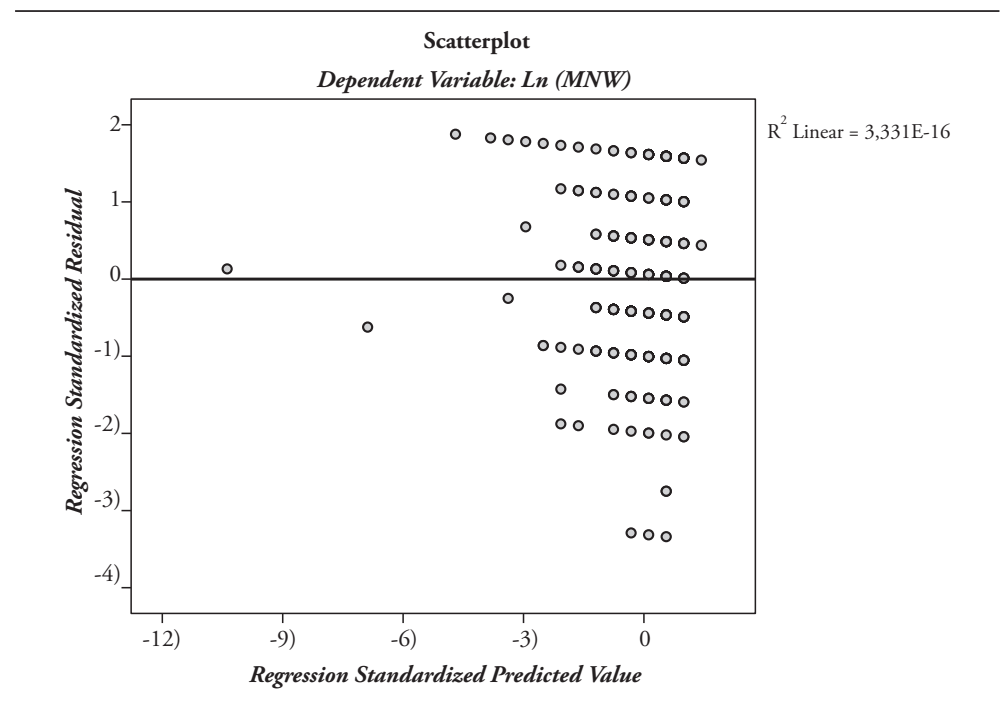

Breusch-Pagan test for heteroskedasticity

Ho: homoskedasticity

H1: heteroskedasticity

$g_{i}=$ Residual $_{i}^{2} /(71.90 / 474), i=1, \ldots, 474$

Breusch-Pagan Statistics $=N^{*} R$ Square $=474^{*} 0.097=45.978$

Chi Square $(45.978,42)=0,310897275$

Do not reject Ho.

\begin{tabular}{l|c|c|c|c|c|c}
\hline & \multicolumn{3}{c}{ Descriptive Statistics for Residual Squared } & & Std. \\
& N & Minimum & Maximum & Sum & Mean & $\begin{array}{c}\text { Stdion } \\
\text { Deviation }\end{array}$ \\
\hline ResSQ & 474 &, 00 & 1,53 & 71,90 &, 1517 &, 20259 \\
\hline Valid N (listwise) & 474 & & & & & \\
\hline
\end{tabular}




\begin{tabular}{|c|c|c|c|c|c|c|}
\hline \multicolumn{7}{|c|}{ ANOVA for regression when $g$ is dependent variable } \\
\hline \multicolumn{2}{|c|}{ Model } & $\begin{array}{l}\text { Sum of } \\
\text { Squares }\end{array}$ & df & $\begin{array}{l}\text { Mean } \\
\text { Square }\end{array}$ & $\mathbf{F}$ & Sig. \\
\hline \multirow[t]{3}{*}{1} & Regression & 82,086 & 42 & 2,932 & 1,713 &, 014 \\
\hline & Residual & 761,594 & 445 & 1,711 & & \\
\hline & Total & 843,680 & 473 & & & \\
\hline
\end{tabular}

\begin{tabular}{|c|c|c|c|c|}
\hline \multicolumn{5}{|c|}{ Model Summary for regression when $g$ is dependent variable } \\
\hline Model & $\mathbf{R}$ & R Square & Adjusted R Square & Std. Error of the Estimate \\
\hline 1 & ,312 & ,097 &, 040 & 1,30822 \\
\hline
\end{tabular}




\section{Appendix G}

\section{Testing Normality of Residuals in SPSS}

We perform the tests for the normality of residuals on 1) studentized and 2) standardized residuals.

\section{1) Studentized residuals}

Ho: Residuals are normally distributed

H1: Residuals are not normally distributed

\begin{tabular}{|c|c|c|c|c|c|c|}
\hline \multicolumn{7}{|c|}{ Tests of Normality } \\
\hline & \multicolumn{3}{|c|}{ Kolmogorov-Smirnov } & \multicolumn{3}{|c|}{ Shapiro-Wilk } \\
\hline & Statistic & df & Sig. & Statistic & df & Sig. \\
\hline Studentized Residual &, 035 & 474 & ,200* & ,992 & 474 & ,068 \\
\hline
\end{tabular}

${ }^{\text {a }}$ Lilliefors Significance Correction

* This is a lower bound of the true significance.

The p-value of the Kolmogorov-Smirnov test for normality of residuals is well above the critical value of 0.05 , while the one of Shapiro-Wilk does not reject the null hypothesis of normality only at the 10 percent level of significance. However, we believe both provide reasonable evidence that residuals are normally distributed. Normality could be also confirmed visually from the histogram below and the Q-Q plot. 

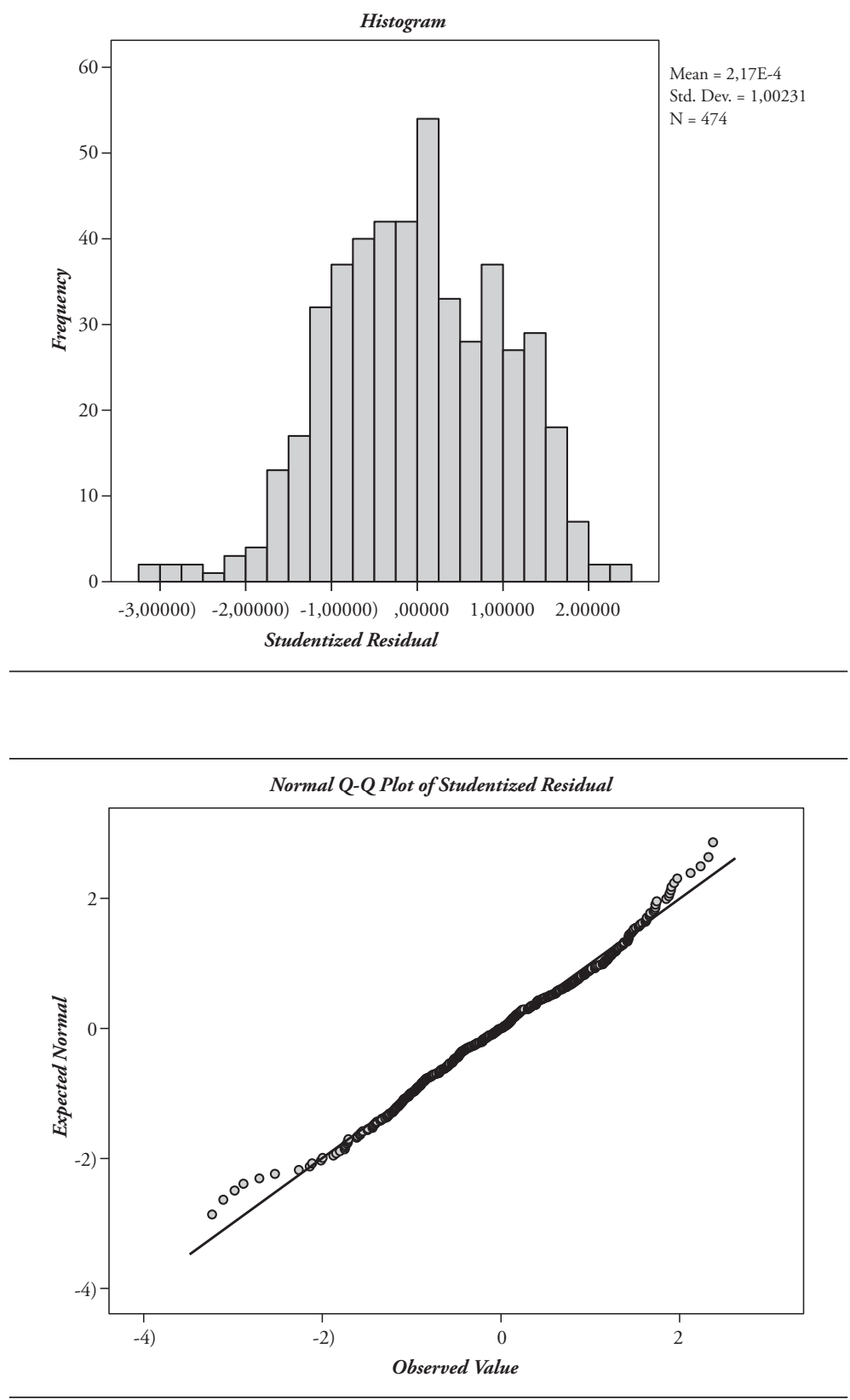


\section{2) Standardized residuals}

Ho: Residuals are normally distributed

H1: Residuals are not normally distributed

\begin{tabular}{|c|c|c|c|c|c|c|}
\hline \multicolumn{7}{|c|}{ Tests of Normality } \\
\hline & \multicolumn{3}{|c|}{ Kolmogorov-Smirnov ${ }^{\mathrm{a}}$} & \multicolumn{3}{|c|}{ Shapiro-Wilk } \\
\hline & Statistic & df & Sig. & Statistic & df & Sig. \\
\hline Studentized Residual &, 035 & 474 & ,200* & 992 & 474 & ,069 \\
\hline
\end{tabular}

${ }^{a}$ Lilliefors Significance Correction

* This is a lower bound of the true significance.

Similarly, as the previous results, we see that the p-value of the Kolmogorov-Smirnov test for normality is well above the critical value of 0.05 , while the one of ShapiroWilk does not reject the null of normality only at the 10 percent. However, we believe both provide reasonable evidence that residuals are normally distributed. Normality could also be confirmed visually from the histogram below and the Q-Q plot.

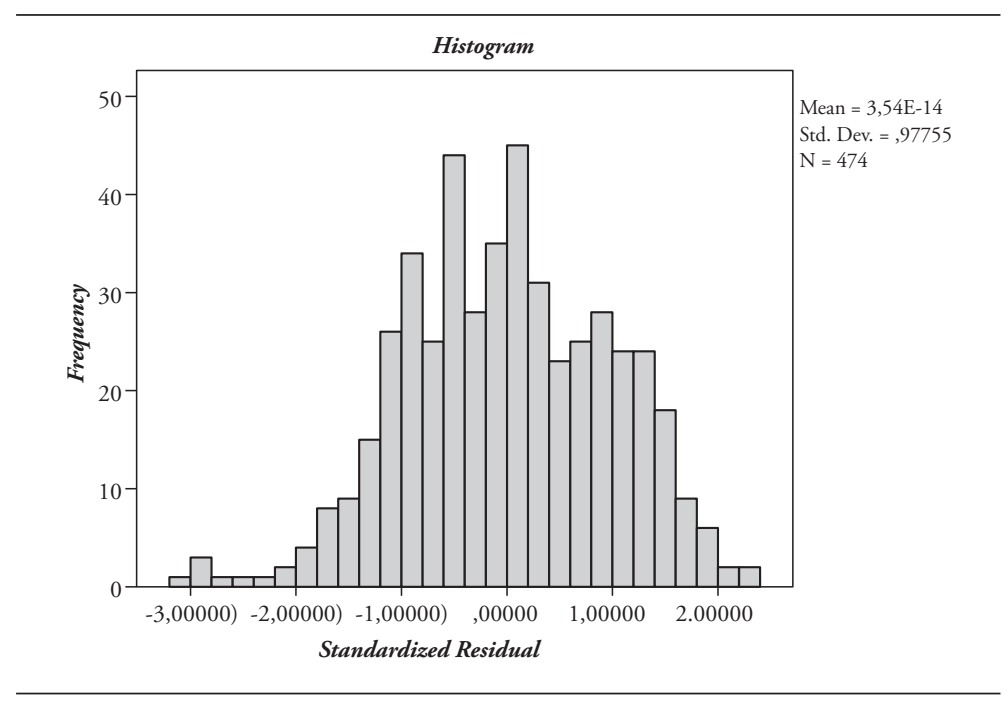




\section{Normal Q-Q Plot of Standardzed Residual}

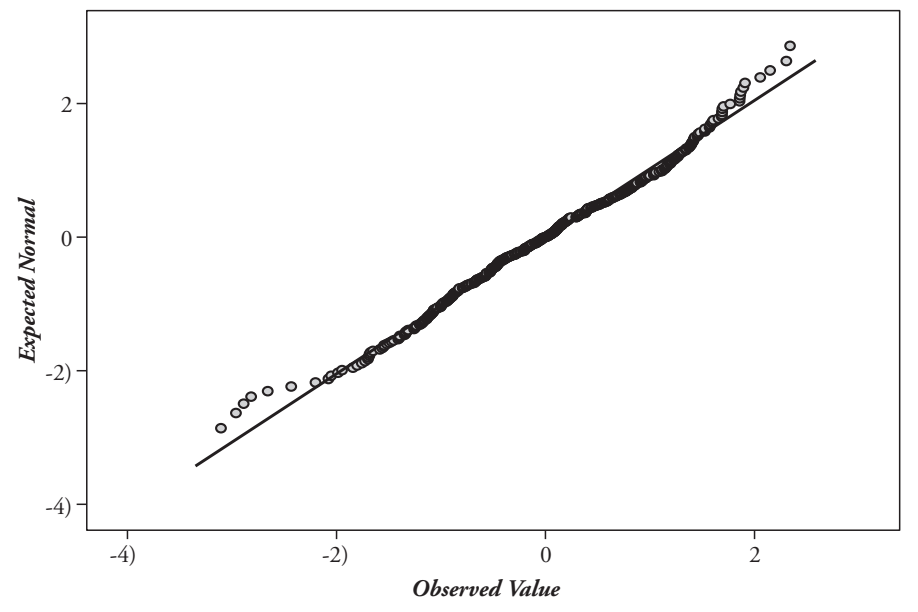




\section{Literature}

Anchor, John R., Jana Fišerová, Kateřina Maršíková, Václav Urbánek, 2011, "Students Expectations of the Financial Returns to the Higher Education in the Czech Republic and England: Evidence from Business Schools", Economics of Education review, 30(4), pp. 673-681. http://dx.doi.org/10.1016/j. econedurev.2011.02.005

Avlijaš, Sonja, Nevena Ivanović, Marko Vladisavljević, Sunčica Vujić, 2013, Gender Pay Gap in the Western Balkan Countries: Evidence from Serbia, Montenegro and Macedonia, Belgrade: FREN - Foundation for the Advancement of Economics.

Betts, Julian R., 1996, "What Do Students Know About Wages? Evidence from a Survey of Undergraduates", Journal of Human Resources, 31(1), pp. 27-56. http:// dx.doi.org/10.2307/146042

Borrego, Cesar Alonso and Antonio Romero Medina, 2010, "Wage Expectations for Higher Education Students in Spain”, Working Paper Economic Series, No. 1016, Madrid: Universidad Carlos III de Madrid.

Botelho, Anabela and Ligia Costa Pinto, 2004, "Students' Expectations of the Economic Returns to College Education. Results of Controlled Experiment", Economics of Education Review, 23(6), pp. 645-653.

Brunello, Giorgio, Claudio Lucifora and Rudolf Winter-Ebmer, 2001, "The Wage Expectations of European College Students", CEPR Discussion Paper, No. 2817, London, UK: Centre for Economic Policy Research.

Brunello, Giorgio, Claudio Lucifora and Rudolf Winter-Ebmer, 2004, "The Wage Expectations of European Business and Economics Student", Journal of Human Resources, 39(4), pp. 1116-1142. http://dx.doi.org/10.2307/3559041 
Carvajal, Manuel J., David Bendana, Alireza Bozorgmanesh, Miguel A. Castillo, Katayoun Pourmasiha, Priya Rao and Juan A. Torres, 2000, "InterGender Differentials between College Students' Earnings Expectations and the Experience of Recent Graduates", Economics of Education Review, 19(3), pp. 229243. http://dx.doi.org/10.1016/S0272-7757(99)00034-5

Chevalier, Arnaud, 2004, "Motivation, Expectations and the Gender Pay Gap for UK Graduates", IZA Discussion Paper, No. 1101, Bonn: Institute for the Study of Labor.

Delaney, Liam, Colm P. Harmon and Cathy Redmond, 2011, "Parental Education, Grade Attainment and Earnings Expectations among University Students", IZA Discussion Paper, No. 5646, Bonn: Institute for the Study of Labor.

Dominitz, Jeff and Charles F. Manski, 1994, "Eliciting Student Expectations of the Returns to Schooling", Discussion Paper No. 1049-94, Institution for Research on Poverty.

Epple, Dennis and Richard Romano, 1998, "Competition between Private and Public Schools, Vouchers and Peer-Group Effects", The American Economic Review, 88(1), pp. 33-62.

Filippin, Antonio and Andrea Ichino, 2003, "Gender Wage Gap in Expectations and Realizations", IZA Discussion Paper, No. 825, Bonn: Institute for the Study of Labor.

Jerrim, John, 2008, "Wage Expectations of UK students: How Do They Vary and Are They Realistic?”, Working Paper A08/08, Southampton, UK: University of Southampton, Southampton Statistical Sciences Research Institute.

Kudryavtsev, Andrey and Gil Cohen, 2010, "Anchoring and Pre-Existing Knowledge in Economic and Financial Settings", American Journal of Social and Management Sciences, 1(2), pp. 164-180. 
Manski, Charles F., 1993, "Adolescent Econometricians: How Do Youth Infer the Returns to Schooling?” in Charles T. Clotfelter and Michael Rothschild, eds., Studies of Supply and Demand in Higher Education, pp. 43-60, Chicago, IL: NBER Books, University of Chicago Press.

Mazza, Jacopo and Joop Hartog, 2011, "Do They Understand the Benefits From Education? Evidence on Dutch High School Students' Earnings Expectations”, IZA Discussion Paper, No. 5714, Bonn: Institute for the Study of Labor.

McElroy, Todd and Keith Dowd, 2007, "Susceptibility to Anchoring Effects: How Openness-to-Experience Influences Responses to Anchoring Cues", Judgment and Decision Making, 2(1), pp. 48-53.

McMahon, Walter and Alan P. Wagner, 1981, "Expected Returns to Investment in Higher Education", Journal of Human Resources, 16(2), pp. 274-285. http:// dx.doi.org/10.2307/145512

Mincer, Jacob, 1974, Schooling, Experience and Earnings, New York, NY: Columbia University Press.

Mojsoska-Blazevski, Nikica, 2006, "The Public Employment Service, Education and Labour Markets in Macedonia", Skopje: Nam Press.

Mojsoska-Blazevski, Nikica and Maja Ristovska, 2012, "Is Government Effective in Promoting Human Capital? The Case of Macedonia” in Mihail Arandarenko and William Bartlett, eds., Labour Market and Skills in the Western Balkans, pp. 129-155, Belgrade: FREN - Foundation for the Advancement of Economics.

State Statistical Office, 2012, "Graduated Students, 2011”, Population and Social Statistics, State Statistical Office.

State Statistical Office, 2013, "Enrolled Students in 2011/12”, Population and Social Statistics, State Statistical Office.

Varga, Júlia, 2001, "Earnings Expectations and Higher Education Enrolment Decision in Hungary”, Budapest Working Papers on the Labour Market, No. 2001/10, Budapest: Institute of Economics, Hungarian Academy of Sciences. 
Vujacic, Ilija, Snezana Djordjevic, Maja Kovacevic and Ivana Sunderic, 2013, "Overview of Higher Education and Research Systems in the Western Balkans", NORGLOBAL Programme of the Norwegian Research Council, No.203340, http://www.herdata.org/public/HE_and_Research_in_Macedonia_FINAL.pdf

Webbink, Dinand and Joop Hartog, 2004, "Can Students Predict their Starting Salary? Yes!", Economics of Education Review, 23(2), pp. 103-113. http://dx.doi. org/10.1016/S0272-7757(03)00080-3

Williams, Gareth and Alan Gordon, 1981, "Perceived Earnings Functions and Ex Ante Rates of Return to Post Compulsory Education in England", Higher Education, 10(2), pp. 199-227. http://dx.doi.org/10.1007/BF00129132

Wolter, Stefan C., 2000, "Wage Expectations: A Comparison of Swiss and US Students", Kyklos, 53(1), pp. 51-69. http://dx.doi.org/10.1111/1467-6435.00109

Wolter, Stefan C. and Andre Zbinden, 2001, "Rates of Return to Education: The View of Students in Switzerland", IZA Discussion Paper, No. 371, Bonn: Institute for the Study of Labor. 